\title{
SUSCEPTIBILITY OF SACCHAROMYCES CEREVISIAE AND LACTIC ACID BACTERIA FROM THE ALCOHOL INDUSTRY TO SEVERAL ANTIMICROBIAL COMPOUNDS
}

\author{
Pedro de Oliva-Neto ${ }^{1 *}$; FumioYokoya ${ }^{2}$ \\ ${ }^{1}$ Departamento de Ciências Biológicas, Faculdade de Ciências e Letras de Assis, Universidade Estadual Paulista-UNESP, \\ Assis, SP, Brasil. ${ }^{2}$ Departamento de Ciência de Alimentos, Faculdade de Engenharia de Alimentos, \\ Universidade Estadual de Campinas-UNICAMP, Campinas, SP, Brasil
}

Submitted: February 14, 2000; Returned to authors for corrections: April 25, 2000; Approved: March 16, 2001

\begin{abstract}
The antimicrobial effect of several products including commercial formulations currently used in sugar and alcohol factories was determined by adapted MIC (Minimal Inhibitory Concentration) test on Saccharomyces cerevisiae and on natural contaminants Lactobacillus fermentum and Leuconostoc mesenteroides. The MIC test by macrodilution broth method was adapted by formulating of the culture medium with cane juice closely simulating industrial alcoholic fermentation must. Acid penicillin V (MIC 0.10-0.20 $\mu \mathrm{g} / \mathrm{ml}$ ) and clindamycin (MIC 0.05-0.40 $\mu \mathrm{g} / \mathrm{ml}$ ) were most effective against bacterial growth in $24 \mathrm{~h}$. Among the chemicals, sulphite (MIC 10-40 $\mu \mathrm{g} / \mathrm{ml}$ ), nitrite (MIC <117 $\mu \mathrm{g} / \mathrm{ml}$ ) and copper sulphate $(75-300 \mu \mathrm{g} / \mathrm{ml})$ were the most effective. Zinc and manganese ethylene-bis-dithiocarbamate and dimethyldithiocarbamate did not show good inhibitory effect on bacteria (MIC $>50 \mu \mathrm{g} / \mathrm{ml}$ ). Methyldithiocarbamate was efficient only on $L$. fermentum (MIC $2.5 \mu \mathrm{g} /$ $\mathrm{ml}$ ) and S. cerevisiae (MIC $5.0 \mu \mathrm{g} / \mathrm{ml}$ ). Thiocianate (MIC 1.2-5.0 $\mu \mathrm{g} / \mathrm{ml}$ ), bromophenate (MIC 9-18 $\mu \mathrm{g} / \mathrm{ml}$ ) and n- alkyldimethylbenzylammonium cloride (MIC 1-8 $\mu \mathrm{g} / \mathrm{ml}$ ) affected $S$. cerevisiae at similar inhibitory concentration for L. mesenteroides or L. fermentum. Formaldehyde was more effective on bacteria (MIC 11.5 $-23 \mu \mathrm{g} / \mathrm{ml}$ ) in both $\mathrm{pH}$ (4.5 and 6.5) than yeast (MIC 46-92 $\mu \mathrm{g} / \mathrm{ml}$ ). Several tested formulated biocides seriously affect $S$. cerevisiae growth in the similar dosages of the bacterial inhibition, so these products should be avoided or used only in special conditions for the bacterium control of fermentation process. For this step, the control of these contaminants by antibiotics are more suitable and effective.
\end{abstract}

Key words: Antimicrobial compound, MIC, S. cerevisiae, lactic acid bacteria

\section{INTRODUCTION}

Lactic acid bacteria, Lactobacillus and Leuconostoc, are common contaminants of yeast alcoholic fermentation and are frequently associated with process problems $(10,16)$. Commercial fuel ethanol in Brazil is currently produced by fed-batch or continuous fermentation process of sugar cane by Saccharomyces cerevisiae with cell recycle. Microbial contaminants are also recycled with yeast and this may cause many problems due to the competition between bacteria and yeasts for the same substrate. Lactobacillus is adapted to the alcoholic and nutritional conditions of the process (17), but Leuconostoc is more sensitive to alcohol and usually does not persist for long period in alcoholic fermentation (14). In addition to acid production, Lactobacillus causes serious problems of yeast flocculation in the alcoholic fermentation $(20,24)$. The antagonism between Lactobacillus and Saccharomyces cerevisiae is due to organic acids produced by the bacterial cells. Lactic acid can strongly inhibit yeast metabolism and decrease alcoholic yield. Essia-Ngang et al. (8) observed 30\% decrease in ethanol yield by yeast fermentation of beet sugar with $5 \mathrm{~g}$ lactic acid/l produced by lactic acid bacteria contamination. Maiorella et al. (15) noted an $80 \%$ reduction in

\footnotetext{
* Corresponding author. Mailing address: Departamento de Ciências Biológicas, Faculdade de Ciências e Letras de Assis, UNESP, Caixa Postal 335, CEP 19800-000, Assis, SP, Brasil. Fax: (+5518) 322-2933. E-mail: poliva@ assis.unesp.br
} 
the yeast population in the presence of $40 \mathrm{~g}$ lactic acid/l. Alcoholic fermentation and yeast viability are strongly reduced by $L$. fermentum after a few cycles in a fed-batch process with cell recycles, if a method of bacterial control is ommitted (17).

The bacterial control in industrial fuel alcoholic fermentation in Brazil is currently done by sulphuric acid washing of yeast cell suspension $(5,22)$. Sometimes, this process helped by addition of biocides in wort such as carbamates, quaternary ammonium compounds, halogenated phenols and antibiotics (penicillin, virginiamicin, Kamoran $\mathrm{HJ}$ ).

Some antibiotics such as tetracycline (2) and chloramphenicol (1) have been tested in alcoholic fermentations but have proven to be unsuitable for industrial applications. Bacterial contaminants are frequently adaptable to the products used for their control particularly antibiotics which makes industrial control difficult (7). Recently 3,4,4' trichlorocarbanilide imobilized in calcium alginate was proposed to control Lactobacillus fermentum in alcoholic fermentation (19). This product showed bacterial inhibition in dosage that did not affect Saccharomyces cerevisiae. Biocides currently used in industrial fuel alcoholic fermentation in Brazil were usually effective against growth of bacterial contaminants, but could affect yeast at similar concentration. This paper shows the results of the antimicrobial ability of several products including commercial formulations used in industrial alcoholic fermentation. The effect on bacterial contaminants from alcohol industry was compared to the effect on Saccharomyces cerevisiae.

\section{MATERIALS AND METHODS}

\section{Microorganisms}

The cultures used in this work were obtained from Tropical Culture Collection (CCT), Campinas - Brazil: Saccharomyces cerevisiae CCT 0472, Lactobacillus fermentum CCT 1400 and Leuconostoc mesenteroides CCT 0367 (both were isolated from
Brazilian distilleries with serious problems of bacterial contamination), L. fermentum CCT 0559 and L. mesenteroides CCT 0582 (from American Type Culture Collection, ATCC 9338 and ATCC 10830, respectivelly). The maintenance medium was Man Rogosa \& Sharpe (Difco) for bacteria and Yeast Malt Extract (Difco) for yeast.

\section{Minimal Inhibitory Concentration (MIC)}

MIC of the products was determined by adapted macrodilution broth method (13), in tubes with $6 \mathrm{ml}$ medium containing $40 \mathrm{~g} / \mathrm{l}$ dry cane juice (concentrated and dryed natural cane juice) and $5.0 \mathrm{~g} / \mathrm{l}$ yeast extract (Difco) dissolved in distilled water and $\mathrm{pH} 4.5$ corrected with $1 \mathrm{~N} \mathrm{HCl}$ (18). As the results were intended for application in sugar cane and alcohol factories, the medium formulation was designed as closely as possible to duplicate commercially extracted cane juice. The tubes were sterilized at $121^{\circ} \mathrm{C}$ during $15 \mathrm{~min}$. The inoculum was standardized according to Macfarland 0.5 standard (13) in aseptic conditions. The cultures were incubated at $30^{\circ} \mathrm{C}$. The bacterial and yeast cells growth were asepticaly measured by absorbance at $600 \mathrm{~nm}$ with a spectrophotometer. MIC for each product was performed in two or three replications and shown as averages. Statistical analysis was carried out to compare averages in treatments (Unpaired t test, ANOVA and Tukey-Krammer Multiple Comparison test) with the Graphpad Instat statiscal program (Rutgers University). MIC of all products including commercial formulations were calculated by amount of active product in pure base.

The list of formulated chemicals tested for minimal inhibitory concentration (MIC) on yeast and bacterial cells is shown in Table 1. Most of them were commonly recommended by different companies for use in microbial control in sugar and alcohol factories. Other tested chemicals were lysozyme (Sigma), copper sulphate (Vetec, Brazil), trisodium polyphosphate (Cinética

Table 1. Formulated chemicals tested for minimal inhibitory concentration (MIC) on yeast and lactic acid bacteria.

\begin{tabular}{ccc}
\hline Active chemicals & Trade name & Company \\
\hline Zinc Manganese ethylene bis dithiocarbamate & - & Dithane-Mancozeb \\
Methyl dithiocarbamate & Buzan 40 & Buckmann Lab. \\
Dimethyldithiocarbamate & Buzan 85 & Buckmann Lab. \\
3 Methyl 4 chlorine phenol & Preventol CMK & Bayer \\
2 Benzyl 4 chlorine phenol & Preventol BP & Bayer \\
o-phenyl phenol & Preventol o extra & Bayer \\
Bromophenate & Biopen 400 & Aquatec \\
2 chlorine acetamide & - & Sigma \\
Tenzyl alcohol mono (poly) formaldehyde & Preventol D2 & Bayer \\
Thyocyanate & Buzan 110 & Buckmann Lab. \\
Formaldehyde & - & Indústria Química Arujá \\
Glutaraldehyde & - & Cinética Química Ltda. \\
\end{tabular}


Química Ltda. Brazil), sodium sulphite (B.Herzog, Brazil), sodium sorbate (Fluka, AG), sodium phosphate (Ecibra, Brazil), sodium nitrite (MB Lab. Quim., Brazil) and tannin (Sigma). The following antibiotics were also included in the experiments: acid penicillin V (Squibb, Brazil), frequently used by different alcohol industries, clindamycin (Upjohn, Brasil) and cephamandole (Sigma).

\section{RESULTS AND DISCUSSION}

MICs of several products on Leuconostoc mesenteroides and Lactobacillus fermentum, microorganisms involved in contamination of sugar cane extraction plant and alcoholic fermentation measured in comparison with MIC on Saccharomyces cerevisiae (Tables 2 and 3). For the antibiotic acid penicillin V, MIC average at $\mathrm{pH} 4.5$ and $24 \mathrm{~h}$. for $L$. fermentum $(0.15 \mu \mathrm{g} / \mathrm{ml}$ or $158 \mathrm{IU} / \mathrm{l})$ was not different $(\mathrm{p}>0.05)$ than for L. mesenteroides $(0.14 \mu \mathrm{g} / \mathrm{ml})$. In contrast, Cruz et al. (7) reported that 500-1000 IU/L of this antibiotic was necessary in the must to prevent bacterial infections, while Bayer et al. (3), working with 40 strains of Lactobacillus, reported a MIC value of $0.48 \mu \mathrm{g} / \mathrm{ml}$ and $\mathrm{MBC}$ (maximum bactericide concentration) of 10 and $100 \mu \mathrm{g} / \mathrm{ml}$ of penicillin respectively to kill 22 and $100 \%$. Currently, the industrial process of alcoholic fermentation uses 1 to $4 \mu \mathrm{g} / \mathrm{ml}$ of penicillin in the must every 2 weeks, to control the bacterial infection within $10^{5}$ to $10^{7}$ cell $/ \mathrm{ml}$.
Clindamycin (Table 2) was an efficient bacterial growth inhibitor with MIC of 0.05 and $0.40 \mu \mathrm{g} / \mathrm{ml}$, for both bacteria genera, but the cost is more expensive than penicillin. Cephamandole was less active ( $\mathrm{p}<0.05)$ in L. mesenteroides (MIC average $1.16 \mu \mathrm{g} /$ $\mathrm{ml}$ ) than in L. fermentum (MIC average $0.31 \mu \mathrm{g} / \mathrm{ml}$ ). In contrast, Bayer et al. (4) found that $20 \mu \mathrm{g} / \mathrm{ml}$ of cephamandole inhibited the growth of $97 \%$ strains of Lactobacillus.

Sodium sulphite (MIC 10-40 $\mu \mathrm{g} / \mathrm{ml}$ ), sodium nitrite (MIC $<58$ to $117 \mu \mathrm{g} / \mathrm{ml})$ and copper sulphate $(75-300 \mu \mathrm{g} / \mathrm{ml})$ were most effective salts for lactic acid bacteria tested in $\mathrm{pH} 4.5$ (Table 2 ). The last two chemicals inhibited the yeast in dosage similar to the bacteria, indicating that they were not suitable for control of lactics in alcoholic fermentation. However, only 5,000 $\mu \mathrm{g} / \mathrm{ml}$ of sodium sulphite was active on Saccharomyces cerevisiae, which was very different $(\mathrm{p}<0.001)$ of bacteria MIC. Sodium sulphite is present in concentrated cane molasses about 500-700 $\mathrm{mg} / \mathrm{l}$ and probably affect more bacteria than yeast cells in mixed wort (cane juice and molasses) depending on their ratio. The average of bacteria MIC of sulphite was significatively $(\mathrm{p}<0.03)$ greater in $\mathrm{pH} 6.5(410 \mu \mathrm{g} / \mathrm{ml})$ than $\mathrm{pH} 4.5(22.5 \mu \mathrm{g} / \mathrm{ml})$, which agreed with Foegeding and Busta (9) who indicated that the best $\mathrm{pH}$ was below 4.0. The antibacterial action of sulphite in water solution at various $\mathrm{pH}$ was investigated by Carr et al. (6). Within $\mathrm{pH} 5$ and 9, a mixture of $\mathrm{HSO}_{3}^{-}$and $\mathrm{SO}_{2}{ }^{-2}$ was observed and by decreasing $\mathrm{pH}$, sulphite form increased, which was responsible

Table 2. Minimal inhibitory concentration (MIC), in $\mu \mathrm{g} / \mathrm{ml}$, of several products on lactic acid bacteria and Saccharomyces cerevisiae at $\mathrm{pH} 4.5$ and 6.5 and $30^{\circ} \mathrm{C}$.

\begin{tabular}{lccccccc}
\hline \multirow{1}{*}{ Product } & Time $(\mathrm{h})$ & $\mathrm{pH}$ & S. cerevisiae & \multicolumn{2}{c}{ L. fermentum } & \multicolumn{2}{c}{ L. mesenteroides } \\
\cline { 4 - 8 } & & & CCT 0472 & CCT 1400 & CCT 0559 & CCT0582 & CCT 0367 \\
\hline Copper sulphate & 24 & 4.5 & 75 & 75 & 300 & 75 & 150 \\
& 24 & 6.5 & 140 & 70 & 70 & 65 & 140 \\
Three sodium & & & & & & & \\
polyphosphate & 24 & 4.5 & 5000 & 2500 & 2500 & 5000 & 5000 \\
& 24 & 6.5 & 1250 & 625 & 625 & 2500 & 1250 \\
Sodium sulphite & 24 & 4.5 & 5000 & 40 & 20 & 20 & 10 \\
& 24 & 6.5 & 5000 & 625 & 625 & 312 & 78 \\
Sodium sorbate and & & & & & & & \\
sodium phosphate (1:1) & 24 & 6.5 & 1250 & 1250 & $>2500$ & $>1250$ & 1250 \\
Sodium phosphate & 24 & 6.5 & $>12500$ & 6250 & 12500 & 3125 & 3125 \\
Sodium nitrite & 24 & 4.5 & 234 & 117 & 117 & $<58$ & 117 \\
& 24 & 6.5 & 3750 & 1875 & 469 & 234 & 234 \\
Tannin & 24 & 6.5 & $>302$ & $>302$ & $>302$ & $>302$ & 302 \\
Lysozyme & 24 & 4.5 & $>124$ & $>124$ & $>124$ & $>124$ & $>124$ \\
Acid penicillin V & 15 & 4.5 & OF* & 0.10 & 0.05 & 0.05 & 0.10 \\
Clindamycin & 24 & 4.5 & OF & 0.20 & 0.10 & 0.10 & 0.20 \\
& 15 & 4.5 & OF & 0.10 & 0.05 & 0.20 & 0.05 \\
Cephamandole & 24 & 4.5 & OF & 0.10 & 0.05 & 0.40 & 0.05 \\
& 15 & 4.5 & OF & 0.40 & 0.20 & 0.40 & 0.20 \\
\hline
\end{tabular}

$\mathrm{OF}^{*}-$ no effect. 
Table 3. Minimal Inhibitory Concentration (MIC), in $\mu \mathrm{g} / \mathrm{ml}$, of commercial formulations, for lactic acid bacteria and Saccharomyces cerevisiae, $30^{\circ} \mathrm{C}$ for 24 hours.

\begin{tabular}{lcccrrr}
\hline \multicolumn{1}{c}{ Product } & $\mathrm{pH}$ & \multicolumn{2}{c}{ S. cerevisiae } & \multicolumn{2}{c}{ L. fermentum } & \multicolumn{2}{c}{ Lesenteroides } \\
\cline { 2 - 6 } & & CCT 0472 & CCT 1400 & CCT 0559 & CCT0582 & CCT 0367 \\
\hline Zinc manganese ethylene & & & & & & \\
bis dithiocasbamate & 6.5 & 250 & 250 & $>250$ & $>250$ & $>250$ \\
Methyldithiocarbamate & 4.5 & 5.0 & 2.5 & 2.5 & $>40$ & $>40$ \\
Dimethyldithiocarbamate & 4.5 & 50 & $>50$ & $>50$ & $>50$ & $>50$ \\
3 Methyl 4 chlorine phenol & 4.5 & 37 & 150 & 300 & 150 & 37 \\
2 Benzyl 4 chlorine phenol & 6.5 & 60 & 30 & 60 & 60 & 60 \\
o-Phenyl phenol & 4.5 & 250 & 62.5 & 62.5 & 125 & 62.5 \\
Bromophenate & 4.5 & 9.0 & 18.0 & 18.0 & 9.0 & 9.0 \\
2 chlorine acetamide & 6.5 & $>300$ & $>300$ & $>300$ & $>300$ & $>300$ \\
Benzyl alcohol mono & & & & & & \\
(poly) hemy formaldehyde & 4.5 & 250 & 62.5 & 62.5 & 125 & 62.5 \\
& 6.5 & 62 & 125 & 125 & 62 & 62 \\
Thiocyanate & 4.5 & 2.5 & 5.0 & 1.2 & 5.0 & 5.0 \\
Formaldehyde & 4.5 & 46.2 & 23.1 & 11.5 & 23 & 23 \\
& 6.5 & 92.5 & 11.5 & 23 & 23 & 5.7 \\
Glutaraldehyde & 6.5 & $>300$ & $>300$ & $>300$ & $>300$ & $>300$ \\
n-alkyldimethylbenzyl & & & & & & 1.0 \\
ammonium chloride & 4.5 & 8.0 & 8.0 & 8.0 & & 1.0 \\
\hline
\end{tabular}

for major antibacterial effect. Lactobacillus malli and Leuconostoc mesenteroides showed a fast decrease of ATP at $\mathrm{pH}$ 4.0 when they were submitted to $1 \mathrm{mM}$ sulphite. The antibacterial action decreased at $\mathrm{pH} 6.0$, and $2 \mathrm{mM}$ sulphite at $\mathrm{pH} 5.0$ prevented entirely their growth (12). Lysozyme did not produced any growth inhibitory effect up to $124 \mu \mathrm{g} / \mathrm{ml}$ in bacteria and yeast (Table 2), although according to Shan and King (21) it destroyed 60-70\% cells of the Micrococcus lysodeikticus within $5 \mathrm{~min}$.

The biocides MIC tested in this work are presented in Table 3. Zinc and manganese ethylene bis dithiocarbamate and dimethyldithiocarbamate did not show a satisfactory performance (MIC > $50 \mu \mathrm{g} / \mathrm{ml}$ ). The first compound was described (23) as effective on S. aureus (MIC $2 \mu \mathrm{g} / \mathrm{ml}$ ), but not on S. cerevisiae (MIC $200 \mu \mathrm{g} / \mathrm{ml}$ ). The optimum $\mathrm{pH}$ range for zinc and manganese ethylene bis dithiocarbamate is 5-9 and the probable reason for the ineffectiveness is the unstability in acid medium. Dimethyldithiocarbamate acts better in basic $\mathrm{pH}$. Methyldithiocarbamate was efficacious only on $L$. fermentum (MIC $2.5 \mu \mathrm{g} / \mathrm{ml}$ ) and S. cerevisieae (MIC $5.0 \mu \mathrm{g} /$ $\mathrm{ml}$ ). Thiocyanate (Busan 110) showed MIC on bacteria of 1.2$5.0 \mu \mathrm{g} / \mathrm{ml}$, and on yeast of $2.5 \mu \mathrm{g} / \mathrm{ml}$, which indicated it was unsuitable for alcohol industry. Bromophenate (Biopen 400) was effective on bacteria (MIC 9-18 $\mu \mathrm{g} / \mathrm{ml}$ ) and on yeast (MIC $9 \mu \mathrm{g} / \mathrm{ml}$ ). The MIC average of formaldehyde for $S$. cerevisiae $(69.3 \mu \mathrm{g} / \mathrm{ml})$ was significantly $(\mathrm{F}=9.998, \mathrm{p}<0.05)$ higher than for L. fermentum $(20.2 \mu \mathrm{g} / \mathrm{ml})$ and L. mesenteroides $(18.7 \mu \mathrm{g} /$ $\mathrm{ml})$ at $\mathrm{pH} 4.5$ and 6.5. This product inhibited Gram positive and negative bacteria (S. aureus and E. coli) with $20 \mu \mathrm{g} / \mathrm{ml}$ and caused disruption of cells of several Gram positive and negative bacteria when treated with twice the concentration of MIC (11). Glutaraldehyde (bacterial MIC > $300 \mu \mathrm{g} / \mathrm{ml}$ ) probably reacted with aminated compounds of the must (e.g. protein) and lost the antibacterial activity. Benzyl alcohol mono (poly) hemi formaldehyde was worse than the formaldehyde (MIC $62.5-125 \mu \mathrm{g} / \mathrm{ml}$ ) on bacteria and the effect was close to that on yeast $(62-250 \mu \mathrm{g} / \mathrm{ml})$. n-Alkyl-di-methyl-benzyl ammonium chloride also showed similar MIC on tested microorganisms (bacteria MIC 1-8 $\mu \mathrm{g} / \mathrm{ml}$ and Saccharomyces cerevisiae MIC $8 \mu \mathrm{g} / \mathrm{ml}$ ). Commercially formulated biocides for alcohol industry are normally recommended for application in dosages $10-40 \mu \mathrm{g} / \mathrm{ml}$. They should not inhibit yeast cells of the process, which is one of the most important limitations of their use in alcoholic fermentation. This work showed that current biocides used in industrial fuel alcoholic fermentation in Brazil could affect yeast. In the fermentation step, the antibiotics should be combined with usual methods for controlling bacterial contaminants such as acid washing of yeast in the cell recycle process.

\section{ACKNOWLEDGEMENTS}

The authors thank the Fundação Tropical de Pesquisas e Tecnologia "André Tosello" (Campinas, SP, Brasil) for the maintenance of the cultures, and the Conselho Nacional de Desenvolvimento Científico e Tecnológico (Brasil) for financial support. 


\section{RESUMO}

\section{Susceptibilidade de Saccharomyces cerevisiae e bactérias láticas provenientes de indústrias alcooleiras a vários compostos antimicrobianos}

O efeito antimicrobiano de vários produtos incluindo formulações comerciais usualmente utilizadas em usinas de açúcar e álcool foi determinado pelo teste da Concentração Mínima Inibitória (CMI) adaptada para Saccharomyces cerevisiae e os contaminantes naturais Lactobacillus fermentum and Leuconostoc mesenteroides. $\mathrm{O}$ teste da $\mathrm{CMI}$ foi feito pela adaptação do método da Macrodiluição em caldo pela formulação de um meio de cultivo com caldo de cana em condições similares ao mosto da fermentação alcoólica. Penicilina V Ácida $(\mathrm{CMI}=0,10-0,20 \mu \mathrm{g} / \mathrm{ml})$ e clindamicina $(\mathrm{CMI}=0,05-0,40 \mu \mathrm{g} / \mathrm{ml})$ foram os mais efetivos contra o crescimento bacteriano em 24 horas. Entre os produtos químicos, sulfito (CMI = 10-40 $\mu \mathrm{g} / \mathrm{ml}$ ), nitrito (CMI $<117 \mu \mathrm{g} / \mathrm{ml}$ ) e sulfato de cobre $(\mathrm{CMI}=75-300 \mu \mathrm{g} / \mathrm{ml})$ foram os mais efetivos. Etileno-bis-ditiocarbamato de zinco e manganês e dimetilditilcarbamato não apresentaram efeito inibitório satisfatório (CMI $>50 \mu \mathrm{g} / \mathrm{ml}$ ). Metilditiocarbamato foi eficiente apenas para L. fermentum (CMI $=2,5 \mu \mathrm{g} / \mathrm{ml})$ e $S$. cerevisiae $(\mathrm{CMI}=5,0 \mu \mathrm{g} /$ $\mathrm{ml})$. Tiocianato $(\mathrm{CMI}=1,2-5,0 \mu \mathrm{g} / \mathrm{ml})$, bromofenato $(\mathrm{CMI}=9-18$ $\mu \mathrm{g} / \mathrm{ml}$ ) e n-alquildimetilbenzil cloreto de amônio (CMI= 1-8 $\mu \mathrm{g} /$ $\mathrm{ml}$ ) afetaram o crescimento de $S$. cerevisiae em concentrações inibitórias similares à L. mesenteroides ou L. fermentum. Formaldeido foi mais efetivo contra as bactérias (CMI= 11,5-23 $\mu \mathrm{g} / \mathrm{ml}) \mathrm{em}$ ambos pHs $(4,5$ e 6,5$)$ em relação à levedura $(\mathrm{CMI}=$ 46-92 $\mu \mathrm{g} / \mathrm{ml})$. Vários biocidas testados afetam seriamente o crescimento de $S$. cerevisiae, nas dosagens similares àquelas que inibem as bactérias, portanto estes produtos deveriam ser evitados, ou usados somente em condições especiais, para o controle bacteriano do processo de fermentação. Para esta etapa, o controle destes contaminantes por antibióticos é mais apropriado e efetivo.

Palavras-chave: Compostos antimicrobianos, CMI, S. cerevisiae, bactérias láticas

\section{REFERENCES}

1. Aquarone, E. Influência do cloranfenicol na fermentação alcoólica de melaço de cana diluído. An. Farm. Quim. São Paulo, 10: 39-40, 1959.

2. Aquarone, E. Penicillin and tetracycline as contamination control agents in alcoholic fermentation of sugar cane molasses. Appl. Microbiol., 8: 263268, 1960.

3. Bayer, A.S.; Chow, A.W.; Concepcion, N.; Guze, L.B. Susceptibillity of 40 lactobacilli to six antimicrobial agents with broad Gram positive anaerobic spectra. Antim. Ag. Chemoth., 14: 720-722, 1978.
4. Bayer, A.S.; Chow, A.W.; Concepcion, N.; Guze, L.B. Comparative in vitro activity of five cephalosporins against lactobacilli. Antim. Ag. Chemoth., 16: 112-113, 1979.

5. Bovi, R.; Marques, M.O. The acid treatment on the alcoholic fermentation. Alcool e Açúcar, 3:10-13, 1983.

6. Carr, J.G.; Davies, P.A.; Sparks, A.H. The toxicity of sulfur dioxide towards certain lactic acid bacteria from fermented apple juice. J. Appl. Bacteriol., 40: 201-212, 1976

7. Cruz, M.R.L.; Vairo, M.L.; Gambassi, D.M.; Alterthum, F. Influence of V acid penicillin in the control of bacterial infeccions on alcoholic fermentation. Rev. Microbiol., 16: 138-142, 1985.

8. Essia-Ngang, J.J.E.; Letourneau, F.; Villa, P. Alcoholic fermentation of beet molasses effects of lactic acid on yeast fermentation parameters. Appl. Microb. Biotechnol., 31:125-128, 1989.

9. Foegeding, P.M.; Busta, F.F. Chemical food preservatives. In: Block S.S (ed). Disinfection, Sterilization and Preservation. Lea \& Fehinger, New York, 1991, p.802-832.

10. Gallo, C.R. Determinação da microbiota bacteriana de mosto e de dornas de fermentação alcoólica. Campinas, 1989, 338 p. (Ph.D.Thesis. Faculdade de Engenharia de Alimentos - UNICAMP).

11. Hamilton, W.A. Membrane active antibacterial compounds. In: Hugo, W.B. (ed). Inhibition and Destruction of the Microbial Cell., Academic Press, New York, 1971, 230p.

12. Hinze, H.; Maier, K.; Holzer, H. Rapid decrease of the adenosine triphosfate content in Lactobacillus malli and Leuconostoc mesenteroides after incubation with low concentration of sulphite. Zeitschrift fur Lebensmittel-Untersuchung und Forschung, 172: 389392, 1981.

13. Jones, R.N.; Barry, A.L.; Gavan, T.L.; Washington II, J.A. Susceptibility tests: microdilution and macrodilution broth procedures. In: eds. Lennette, E.H.; Balows, A.; Halousler, W.J. Jr.; Shadom Y. (eds). Manual of Clinical Microbiology, American Society of Microbiology, Washington - DC, 1985, 972p.

14. Kaji, D.A. Influência da temperatura e infecção lática na fermentação alcoólica. Campinas, 1989, 136p. (Master Thesis, Faculdade deEngenharia de Alimentos - UNICAMP).

15. Maiorella, B.; Blanch, H.W.; Wilke, C.R. By product inhibition effects on ethanolic fermentation by Saccharomyces cerevisiae. Biotechn. Bioeng., 25: 103-131, 1983.

16. Oliva-Neto, P. de. Influência da contaminação por bactérias l ácticas na fermentação alcoólica pelo processo de batelada alimentada. Campinas, 1990, 200p. (Master Thesis, Faculdade de Engenharia de Alimentos UNICAMP).

17. Oliva-Neto, P.; Yokoya, F. Evaluation of bacterial contamination in a fedbatch alcoholic fermentation process. World J. Microb. Biotechnol., 10: 697-699, 1994

18. Oliva-Neto, P.; Yokoya, F. Influência do extrato de levedura na estabilidade da fermentação alcoólica contaminada por Lactobacillus fermentum. Ciênc. Tecnol. Aliment., 16: 170-174, 1996.

19. Oliva-Neto, P.; Yokoya, F. Effect of 3,4,4'- trichlorocarbanilide on growth of lactic acid bacteria contaminants in alcoholic fermentation. Biores. Technol., 63: 17-21, 1998.

20. Santos, M.T.; Yokoya, F. Characteristics of yeast cell flocculation by Lactobacillus fermentum. J. Ferment. Bioeng., 75: 151-154, 1992.

21. Shan, S.B.; King, H.K. The action of lysosyme on bacterial electron transport systems. J. Gen. Microbiol., 44: 1-13, 1966.

22. Simpson, W.J.; Hammond, J.R.M. The response of brewing yeast to acid washing. J. Inst. Brewing. 95: 347-354, 1989.

23. Wallhaufser, V.K. Praxis der sterilisation-desinfektion-Konservierungkeimidentifizierung-betriebshygiene. George Thieme (ed), Verlag, Stuttgart, 1984, 851p.

24. Yokoya, F.; Oliva-Neto, P. Characteristics of yeast flocculation by Lactobacillus fermentum. Rev. Microbiol., São Paulo, 22: 21-27, 1991. 